\title{
Diplopia como Manifestação Inicial Rara de Carcinoma
} Gástrico

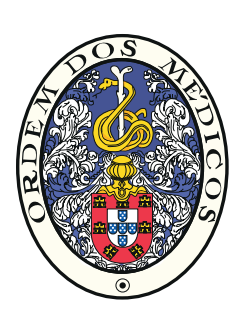

Helena TEMIDO ${ }^{1}$, Filipe VILÃO ${ }^{1}$, Francisco PARENTE ${ }^{1}$

Acta Med Port 2017 Apr;30(4):339-339 - https://doi.org/10.20344/amp.7536

Keywords: Diplopia; Orbital Neoplasms/secondary; Stomach Neoplasms

Palavras-chave: Diplopia; Neoplasias Gástricas; Neoplasias Orbitárias/secundária

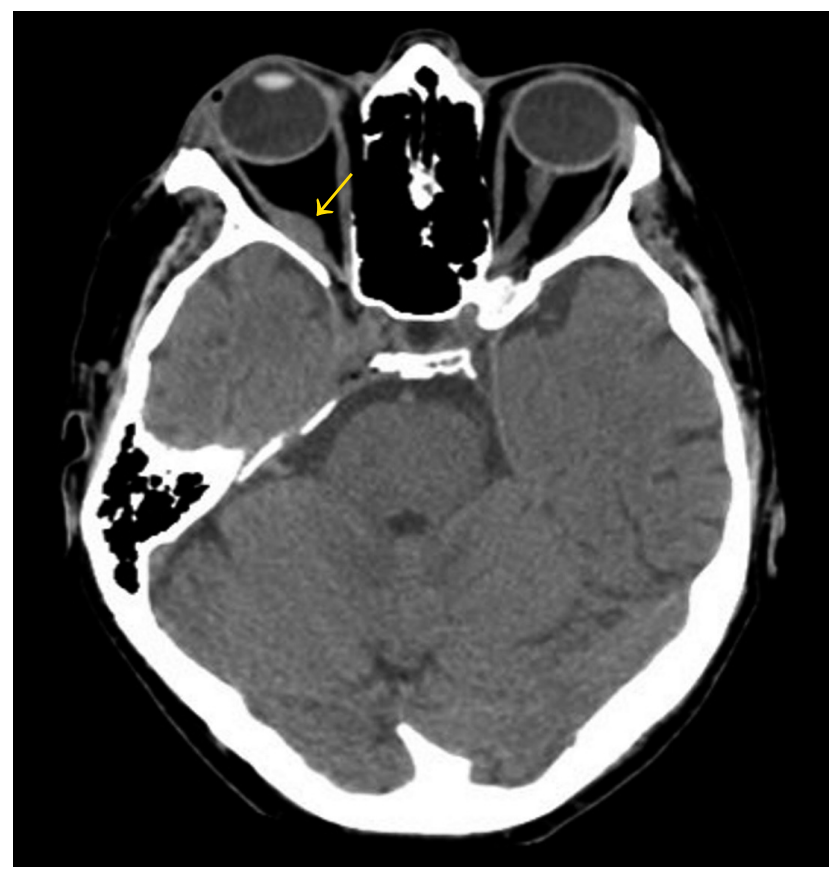

Figure 1 - Lesion $(13 \times 9 \times 9 \mathrm{~mm})$ adjacent to the lateral rectus muscle of the right eye (arrow) without contrast

Forty two years-old male with bilateral pulmonary embolism also complained of limitation on the abduction of the right eye and diplopia when he looked right. The head computed tomography showed a lesion on the lateral rectus muscle of the right eye that, after contrast, seemed metastatic. The etiologic study revealed a signet ring cell gastric carcinoma metastatic to bone and mediastinal and abdominal ganglia. The patient died shortly afterwards. Orbital metastasis are rare occurrences $\left(0.07 \%-4.7 \%{ }^{1}\right.$ of

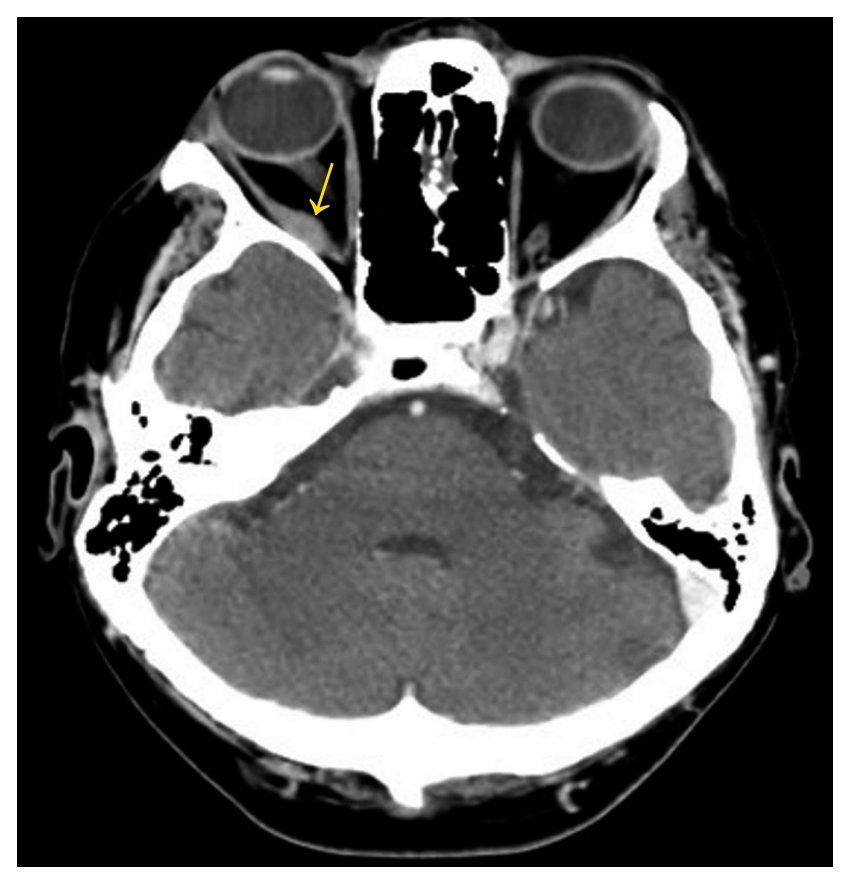

Figure 2 - Lesion (13 $\times 9 \times 9 \mathrm{~mm})$ adjacent to the lateral rectus muscle of the right eye (arrow), with slight enhancement after contrast, suggesting metastasis

all tumours, of which $6 \%-7 \%^{2}$ are gastric) but they must be considered in the differential diagnosis of patients with malignant tumours and diplopia caused by limitation on the abduction of the eye. It is possible, although unusual, to find orbital metastasis involving the extraocular muscles in the absence of previously known neoplastic disease ( $2 \%$ $-15 \%)^{3}$ just as it happened with this patient, in which the gastric carcinoma was diagnosed subsequently.

\section{REFERENCES}

1. Souayah N, Krivitskaya N, Lee HJ. Lateral rectus muscle metastasis as the initial manifestation of gastric cancer. J Neuro-Ophthalmol. 2008;28:240-1.

2. Mutyala V, Bains S, Patil C, Madhavarao B. Bilateral acute ptosis leading to the diagnosis of a presumed metastatic gastric adenocarcinoma. Orbit. 2012;31:134-6.

3. Char DH, Miller T, Kroll S. Orbital metastasis: diagnosis and course. Br J Ophthalmol. 1997;81:186-390.

\footnotetext{
1. Serviço de Medicina Interna A. Centro Hospitalar e Universitário de Coimbra. Coimbra. Portugal.

$\bowtie$ Autor correspondente: Helena Temido. helenatemido@gmail.com

Recebido: 17 de fevereiro 2016 - Aceite: 23 de novembro de 2016 | Copyright @ Ordem dos Médicos 2017
} 